\title{
Land-Use Impact and Nitrate Analysis to Validate DRASTIC Vulnerability Maps Using a GIS Platform of Pablillo River Basin, Linares, N.L., Mexico
}

\author{
René Alberto Dávila Pórcel1, Christoph Schüth ${ }^{2}$, Héctor De León-Gómez¹, Andreas Hoppe², \\ Rowen Lehné ${ }^{2}$ \\ ${ }^{1}$ Facultad de Ingeniería Civil, Universidad Autónoma de Nuevo León, México, Av. Universidad S/N, Cd. \\ Universitaria, San Nicolás de los Garza, México \\ ${ }^{2}$ Institut für Angewandte Geowissenschaften Technische Universität Darmstadt, Schnittspahnstraße 9, \\ Darmstadt, Deutschland \\ Email: rene.alberto.davila@gmail.com
}

Received 29 August 2014; revised 26 September 2014; accepted 21 October 2014

Copyright (C) 2014 by authors and Scientific Research Publishing Inc.

This work is licensed under the Creative Commons Attribution International License (CC BY). http://creativecommons.org/licenses/by/4.0/

(c) (i) Open Access

\section{Abstract}

Preventive management of groundwater resources and their protection against pollution is one of the major challenges of our society. Groundwater systems are related with the surficial processes like territorial administration that is one of the most important tasks into the human development, because it involves serious problems to define the spatial medium, the industrial site-selection and the land-use allocation. Land-use and anthropogenic distribution could be the origin of the emission of pollutants that constitutes a serious health risk in urban areas. Nitrate was used as a pollution indicator in the Pablillo River Basin (PRB), to know the evolution of groundwater quality between 1981 and 2009 using GIS platform linked to vulnerability maps of DRASTIC (Depth to the water table; net groundwater Recharge; Aquifer type; Soil type; Topography; Impact of the vadose zone and hydraulic Conductivity of the saturated zone). The study area is centered on the Linares city; changes in aquifer vulnerability were assessed over time on two stages (2007 and 2001). In both cases, depth from surface to groundwater plays an important role by being the most dynamic variable over time. This study shows that the depth of water table is the key factor in the evaluation of groundwater vulnerability. The significance of land-use impact in contamination process called Index of Pollution Risk (IPR) and nitrate distribution process in the aquifer system was used as anthropogenic indicator together with the IPR in order to associate the land-use, the aquifer-vulnerability and human-activities. The final map of IPR allows determining possible polluted zones verified by high nitrate contents over the aquifer system. Land-use proved to be an important parameter necessary to correct the vulnerability maps using the DRASTIC method. This as- 
sessment is valid for situations where a specific time is defined because six of seven parameters change their properties in a very long term. The IPR-map could be an important key tool to prevent complex scenarios of groundwater contamination and to improve the aquifer management for decision makers, governments and private companies.

\author{
Keywords
}

Vulnerability Maps, DRASTIC, Land Use, Nitrate, GIS

\title{
1. Introduction
}

The foresighted management of groundwater resources and their protection against pollution is one of the major challenges of our society. Especially in developing countries, the fast growing population with the resulting expansion of urban areas and the need to intensify agriculture lead to high potential for pollution. However, the generation of pollutants due to human activities does not always end up polluting groundwater resources; therefore, considering the potential pathway of contaminants from source to contact with groundwater is important. To evaluate this process of contamination, the concept of vulnerability was introduced in the late sixties [1] and several models were developed thereafter to assess aquifer vulnerability in a standardized manner, such as DRASTIC [2], GOD [3], AVI [4], and SINTACS [5]. These models consider morphological, hydrological, soil characteristics, aquifer media, hydraulic conductivity and water table to identify differences in vulnerability. Furthermore, in recent years, these models were frequently integrated into a Geographic Information System (GIS) to generate thematic maps of vulnerability which could be used for development, planning, preventive action or contaminant source identification [6]-[8].

Especially DRASTIC, originally developed by the US Environmental Protection Agency (USEPA) [2], was applied in numerous studies and with various hydrogeological settings [6] [9]-[14]. Vulnerability maps generated with the DRASTIC method contain information on the physical characteristics of the study area used for analyses therefore they cannot be calibrated. The advantages of DRASTIC are: a) the DRASTIC index represents measurable parameters for which data are available, without a detailed reconnaissance and from different sources [2]; b) the interplay of many parameters decreases the probability of neglecting relevant factors and minimizes the effects of an incidental error on model results [15]; and c) the method gives relatively accurate results for extensive areas with complex geological structures [16] [17]. On the contrary, the limitations of DRASTIC method are: a) the selected parameters are mainly based on the physical characteristics of a catchment area, rather than chemical-physical processes [18]; b) important parameters might be attenuated by irrelevant parameters in terms of vulnerability assessment in a particular setting [14] [19]; c) process based parameters, e.g. dispersion, sorption, precipitation or degradation are not included in the analysis; and d) DRASTIC method aims to evaluate groundwater pollution potential from a regional perspective rather than having a site specific focus [2]. However, several modifications to the DRASTIC method were proposed, in general by integrating additional parameters such as land-use to validate or optimize the maps of vulnerability [7] [8] [20]-[23].

In this study, the DRASTIC approaches were applied to evaluate the aquifer vulnerability changes over the time (fourth dimension). To achieve the desired goal, two situations were analyzed: the first approach represents the recent scenario of the aquifer vulnerability in 2007; the second approach is a previous scenario for 2001. Subsequently, the significance of land-use was taking into account in order to ascertain the impact of this parameter in the process of contamination that is represented on a new parameter called Index of Pollution Risk $(I P R)$. Finally, nitrate distribution and its contents are used as fingerprints of the human activity over the time between 1981 and 2009. The nitrate evolution process in the aquifer system was analyzed and used as anthropogenic indicator together with the $I P R$ in order to associate the land-use, the aquifer vulnerability and human activities. The final map IPR allows determining possible polluted zones (verified by high nitrate contents) over the system, directly related to anthropogenic activities identified through the land-use; this map could be an important tool key to prevent complex scenarios of groundwater contamination and to improve the aquifer management in a simple and clear way. In this case, sulphate and chloride are not used as an indicator of human activities, due to its natural conditions into the regional hydrogeological system of the basin. 


\section{The Role of Land-Use Development}

The human requirements are increasing around the world; the socioeconomic activities impose a pressure over natural resources that create a competence and a conflict to reach the correct land-use [24]. Nowadays, the territorial administration is one of the most important tasks into the human development. This involves serious problems to define the spatial medium, the industrial site-selection and the land-use allocation. These are multifaceted challenges and imply technical, economic, social, environmental and politic requirements. The solution to these challenges involves frequently a great analysis complexity into the decision-making process [25]. The main process is urbanization that may lead to waterproofing of land surface in urban areas, depending on landuse changes. This may have effect on groundwater recharge process; consequently, groundwater quality may be impact by changes in overlaying land-use i.e. industrial development, agricultural activity and wastewater generation. Industrial and agricultural impacts depend of industrial and economic development of the city. However, sewage contamination is a global issue and may produce contamination of groundwater results from direct infiltration and from surface runoff entering poorly designed or maintained springs and boreholes [26]-[28]. Under industrialized zones, the subsurface may receive industrial effluents directly or indirectly from disposal to the ground or through seepage from lagoons, surface watercourses or drainage ditches, respectively. The spillage and leakage of hydrocarbons/petroleum products stored on tanks are possible, as well as, a direct spillage onto the road from vehicles is another source. On the other hand, urban areas produce solid waste, where municipal authorities and/or private companies are responsible for it is management, disposal is to landfill or open dumps, which may produce leachate that penetrates the subsurface and threaten groundwater. The type of industries present in the overlying city, and the underlying geology have a particular importance with regard to the natural attenuation capacity [28]. Land-use in developing cities can be complicate by the presence of urban agricultural activities. Access to arable land in urban areas, may offer the possibility of better living in low-income areas. The agriculture in urban and peri-urban areas may vary from small-scale commercial activities down to individual ownership of farm animals for individual subsistence purposes. The larger scale commercial operations (farms) may be a threat to groundwater quality through the production of slurry that may be channel into drainage ditches, surface water bodies and watercourses like rivers [28]. Barrett et al. (2004), demonstrate that the existence of fecal waste on the land surface in urban areas is a common origin of groundwater contamination where the sanitary protection of springs or wells is missing, allowing contaminated surface runoff to directly enter the groundwater system. In general, the consequence of urban expansion experienced by cities and population growth is that water tables are lowered and contamination of shallow groundwater generally occurs through discards of residential and industrial waste to the ground [26] [28].

Linares city experienced a fast and permanent land-use change over the last two decades, where the location of industries generates a rapid population growth, therefore the agricultural sector increase its activity and land coverage in the surroundings of the urban centers. The urbanization process exceeds the capacity of the territorial planning under the responsibility of the local government. In this region, the easiest parameter to evaluate the human impact over the area is land-use that represents directly the human activities and the impact over the natural resources exploitation around the urban area of Linares, for this reason it is important include the land-use distribution into the analysis of aquifer vulnerability.

\section{Nitrate and Its Impact in the Public Health}

Nitrate constitutes a serious health risk at high levels, as it disintegrates in the body into nitrite, which difficult oxygen transfer by binding with hemoglobin and leading to methemoglobinemia, consequently lives of infants is threatened. Furthermore, nitrate is forerunner to the development of the genotoxic N-nitroso compounds (NOC), which are knew animal carcinogens [29]. Nitrate is one of numerous compounds that conforms the nitrogen cycle, which accompanies the larger life/death cycle in the biosphere. Several complex and interrelated processes determine the nitrogen cycle, where atmospheric nitrogen is transform into organic and inorganic nitrogen compounds and back into gaseous form. These processes are fixation, ammonification, synthesis, and nitrification and denitrification [30]. Through biological, atmospheric and industrial fixation, Nitrogen gas, which constitutes $79 \%$ of the atmosphere, is transform into organic nitrogen, ammonium $\left(\mathrm{NH}_{4}\right)$, and nitrate. Organic nitrogen, generally in the form of dead animal and plant tissues and animal fecal matter, disintegrates through the process of ammonification into ammonia $\left(\mathrm{NH}_{3}\right)$ and $\mathrm{NH}_{4}$. Ammonium is oxidized into nitrate $\left(\mathrm{NO}_{2}\right.$, under aerobic conditions), which due to its instability is readily oxidized into nitrate. Known as nitrification, this process is carry 
out by chemoautotrophic bacteria to produce its energy needs. Nitrification depends of several parameters including $\mathrm{pH}$, temperature, microbial population and ammonium concentration. Under anaerobic conditions, other bacteria use nitrate as a substitute of oxygen to oxidize organic material. This process is call denitrification and results in the reduction of nitrate into gaseous nitrogen. Denitrification is influence by factors like availability of organic substrate, moisture, $\mathrm{pH}$, and temperature [28]. In addition, the intense application of fertilizers in agricultural sector, irrigation practices and sewage contamination have dramatically augmented the quantity of nitrogen introduced to the soil and altered the balance of nitrogen compounds in soil and groundwater producing increasingly higher nitrate concentrations. Owing to its solubility and low rate of adsorption to soil particles, nitrate is able to travel great distances from its source. Therefore, the impact of these activities (application of fertilizers) can have a wide geographic extent. For the study case, is clear that in the surrounding area of Linares city there are several citrus growing areas (the traditional economic source), because during the last 20 years human needs impose a great demand for food of plant origin; as a result the application of fertilizers is a common practice throughout the nearby area of Linares. This situation threats directly the soil quality and indirectly the groundwater quality, which is the main source of irrigation water for the agricultural area. Through the nitrate distribution analysis over the study area is possible to know the relationship between human activities to polluted areas, in order to validate and optimize the interpretation of aquifer vulnerability maps.

\section{Study Area}

The study area is located in the northeast of Mexico, approximately $127 \mathrm{~km}$ to southeastern of Metropolitan Area of Monterrey (MAM). Cerro-Prieto dam captures surface water from Pablillo River Basin and supplies drinking water for the growing MAM with $\sim 4.2$ million of inhabitants [31]. This dam is the second largest source of potable water for the biggest Mexican urban center in the north side of the country. On the other hand, Linares city is place in the northeast part of the basin near to Cerro-Prieto dam, a combined system supply drinking water for its population; groundwater sources ( 73 wells) supply more than $50 \%$ of the total volume of drinking water. During the last 20 years, Linares has been experiencing a fast industrial, urban and agricultural expansion where the human activities threaten the groundwater quality and inhabitants health; because of the economic development the major land-use near Linares are: agriculture and growing industrial zone (Figure 1).

The weather conditions i.e. temperature and rainfall has been measured in seven climatologic station (Las Crucitas, Cerro Prieto, Camacho, San Francisco, El Popote, La Laja and Vista Hermosa) during 25 years, where annual rainfall average is $1035 \mathrm{~mm} / \mathrm{yr}$ and the annual average of temperature is $22.2^{\circ}$ Celsius over the flat area of the basin [32]. Figure 2 represents the rainfall isohyets and temperature distribution during 25 years (19822007).

In addition, conditions in semi-arid regions (northeast of Mexico) present specific problems that increase the risk of nitrate contamination to groundwater. Under natural semi-arid conditions, low soil moisture conditions significantly retard the denitrification process leading to accumulation of nitrates in the soil over several years [33] [34]. Those accumulations can be transport to the groundwater by the irrigation, or during major flash flood events that increase the nitrate levels on groundwater. A common practice for managing water scarcity is the alternative of irrigation using treated/undertreated wastewater. This practice has brought significant benefits in terms of increasing availability of good quality water to high priority, meeting agricultural water resulted in important levels of nitrates in groundwater [35]-[39]. Even if wastewater is generally low in nitrate, it contains significant levels of ammonium compounds that convert via nitrification process into nitrate, which later leach into groundwater. Under poor regulations and enforcements, as is the case of Linares city, farmers faced with lack of sufficient water, then the farmers may resort to tapping into highly polluted surface water or groundwater [40] [41]. Accordingly, fertilizers play an even more important role in rising nitrate influx to the soil in semi-arid regions in comparison to more humid conditions. All these variables and practices are present today in the study area identified as a conflictive zone in terms of sustainability of groundwater.

\section{Hydrogeologic Framework}

The Pablillo River Basin is located in the middle of two geologic provinces: a) the Sierra Madre Oriental in the southwestern part of the basin; and b) the Coastal Plain of the Mexican Gulf (CPMG) in the northeastern. The portion in the Sierra Madre Oriental has a mountainous area with few populations; therefore, the study area is 


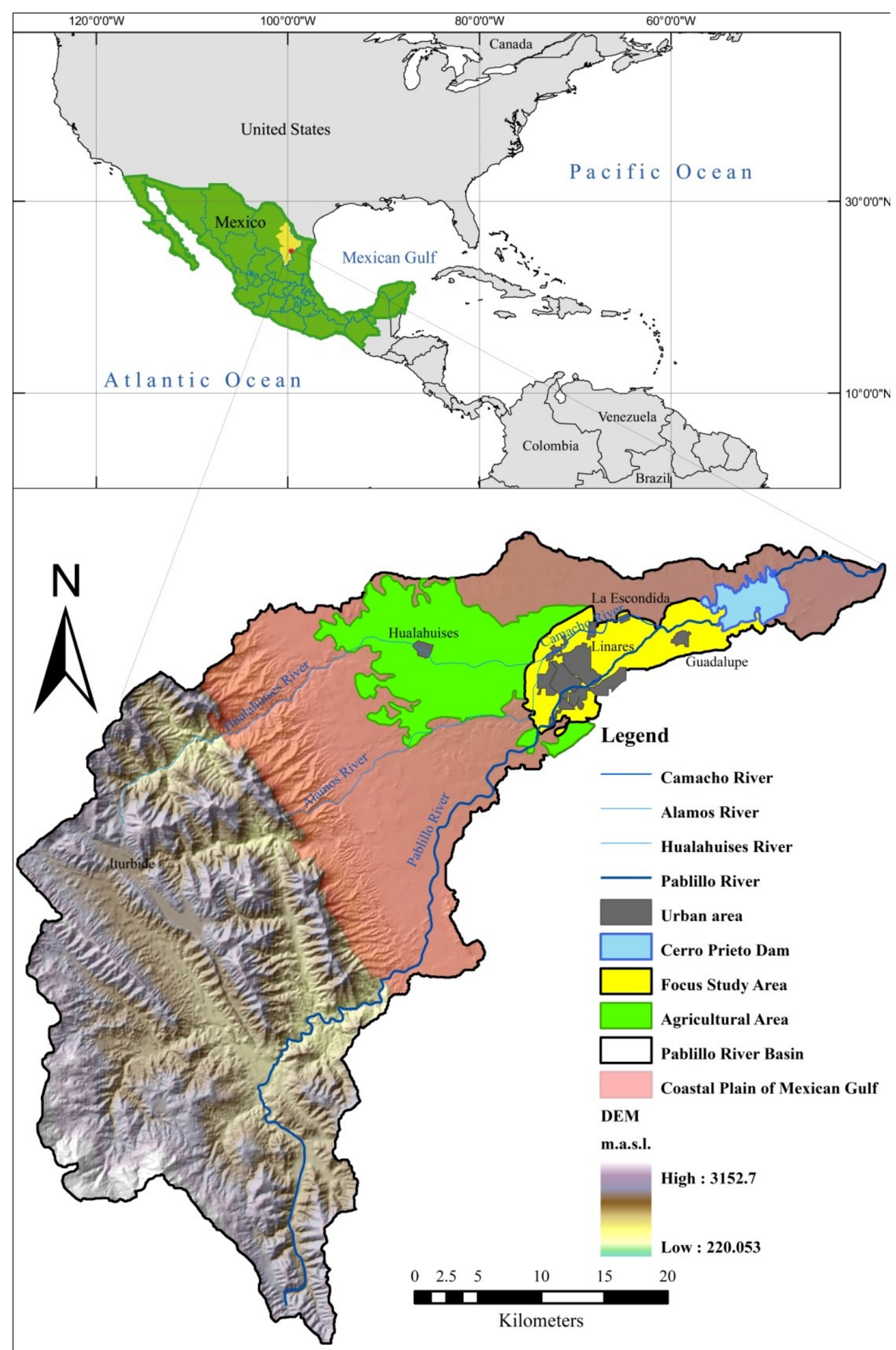

Figure 1. Location of the study area. 


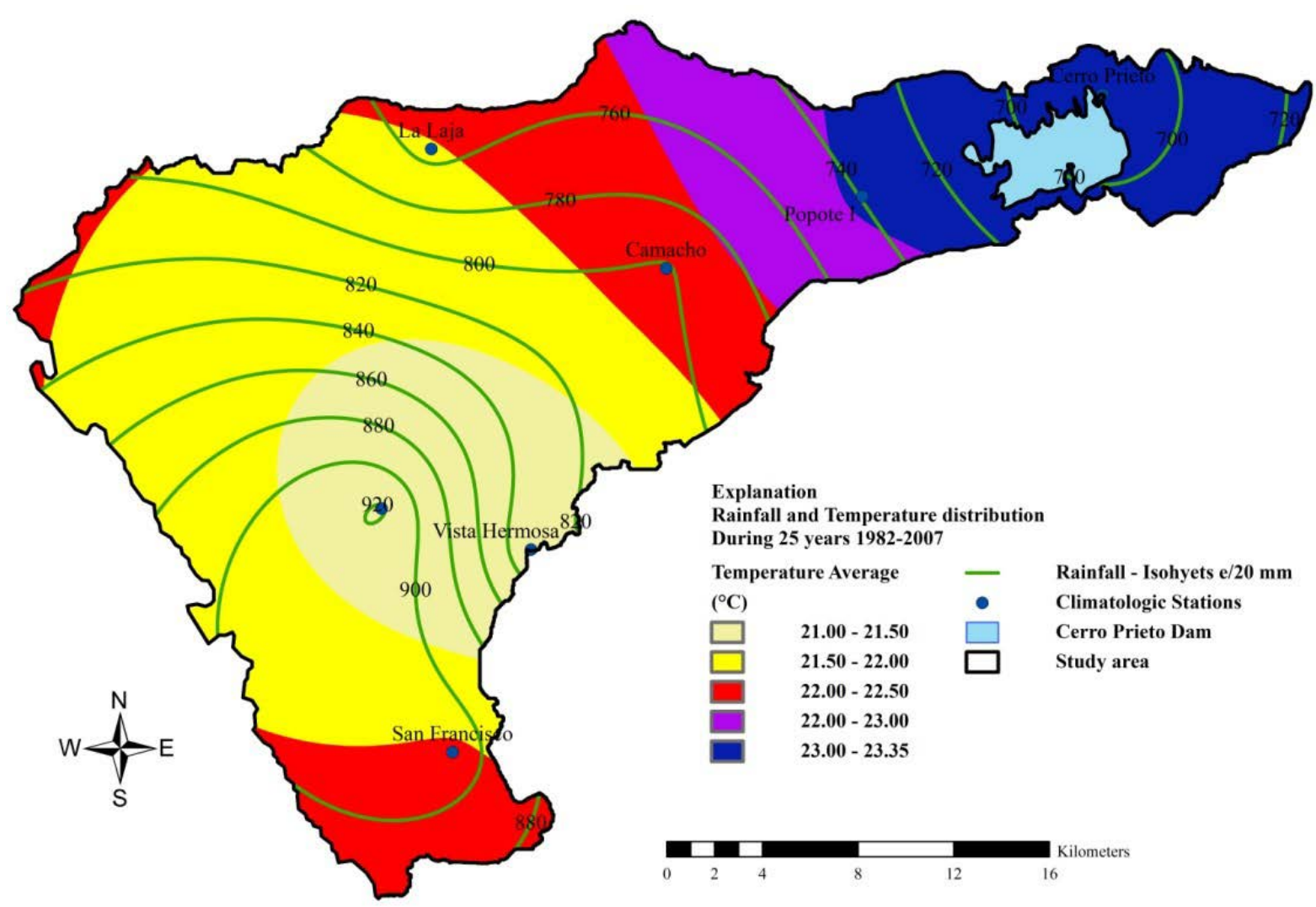

Figure 2. Rainfall isohyets and temperature distribution during 25 years (1982-2007).

limited to the flatter northeastern part surrounding the urban centers inside the basin.

Into the study area two important geological formations can be distinguished: a) the Méndez Formation (Campanian-Maastrichtian) with a maximum thickness of about $1500 \mathrm{~m}$, consisting of dark gray shale interspersed by alive-green and calcareous shale; and b) the fluvial terraces and lacustrine sediments of the Alluvial-Conglomerate Formation (Tertiary-Quaternary), which has a thickness of about 25 m, these sediments originate from the mountains of the Sierra Madre Oriental [42]-[45]. Two hydro-stratigraphic units were defined: a) the Alluvial-Conglomerate Formation represents the porous upper aquifer in the region consisting mainly of gravel and sands, with some silt and clay layers, respectively, this unconsolidated material is underlain by the b) fractured and weathered shale of the Méndez Formation, these units are hydraulically interconnected. Groundwater is stored in the fractured and weathered bedrock shale and the recharge to the aquifers occurs through the overlaying alluvial deposits. Groundwater flow shows a SW-NE direction and the depths average to the water table is about $10 \mathrm{~m}$.

In particular, the alluvial plains surrounding Linares are increasingly use for agricultural development, which leads a serious threat to groundwater quality. Groundwater exploitation from the Alluvial-Conglomerate hydro-stratigraphic unit led to initial decline of groundwater levels compromising the water availability. Currently the groundwater abstraction is from both aquifers (Alluvial-Conglomerate and fractured shale, porous and fractured aquifers respectively).

\section{Materials and Methods}

\subsection{Database and DRASTIC Method Implementation}

To calculate the DRASTIC Vulnerability Index (DVI), seven hydrogeological factors have to be considered and weighted. It is assumed that DRASTIC parameters controlling the infiltration of precipitation and groundwater flow therefore are measures of aquifer vulnerability [2] [12] and the weighting factors are based on their relative significance with respect to pollution potential [46]. 
In the first step, each DRASTIC factor is assigned a relative weight ranging from 1 to 5 , with 5 being the most significant impact and 1 the less significant impact. In the second step, each factor has to be subdivided into ranges or media types that have an impact on pollution potential, these ranges or media types receive ratings between 1 and 10, with 10 being the highest pollution potential and 1 being the lowest pollution potential. Most factors receive one rating per range: other factors i.e. aquifer and vadose zone media receives "typical ratings" or ratings based on site-specific knowledge [2]. With this numerical arrangement could be obtain the DVI value using a simple additive model (Equation (1)).

$$
D V I=D r D w+R r R w+A r A w+S r S w+T r T w+I r I w+C r C w
$$

where " $r$ " is the rating and " $w$ " is the specific weight for each of the DRASTIC factors.

Geological, hydrogeological, topographical, hydrochemical, soil type and climatic data were used to create the database used for assessment of the aquifer vulnerability. These dataset was obtained from previous academic investigations, the Comisión Nacional del Agua (CNA), Servicios de Agua y Drenaje de Monterrey (SADM), Instituto Nacional de Estadística y Geografía (INEGI) and also collected during field campaigns [47][52]. All data were summarized into a geodatabase to allow the generation of the thematic maps in a GIS environment representing the seven interactive parameters. The rating and weighting values are integrated for each parameter into the GIS; the rating values are numerically distributed according to the cell division resembling an aquifer property. The weight impact factor is included through the "Raster Calculator" where each raster cell is multiply by the imposed weighting-factor for each thematic layer of each DRASTIC parameter.

Groundwater recharge was determined using the TURC equation over the areas of Isohyets calculated into the GIS [53] showed in Figure 2 and the obtained values for each sector are detail in Table 1. The following equation was used to determine these values:

$$
\% R=\left(1-\frac{\sqrt{0.9+\frac{P^{2}}{300+25 T+0.05 T^{2}}}}{2}\right) * 100
$$

where:

$P=$ Rainfall average (25 years)

$T=$ Temperature average (25 years)

$\% R=$ Percent of rainfall assumed to be direct recharge.

In Table 1 the rainfall and recharge values are shown; Figure 3(a) represents the recharge over the study area; its values were reclassify according to DRASTIC method.

Table 1. Recharge estimation using Turc's equation (1954).

\begin{tabular}{cccc}
\hline$T$ & $P$ & $R$ & $\% R$ \\
\hline$\left[{ }^{\circ} \mathrm{C}\right]$ & {$[\mathrm{mm} / \mathrm{y}]$} & {$[\mathrm{mm} / \mathrm{y}]$} & {$[\%]$} \\
\hline 23.35 & 700 & 126.62 & $18.09 \%$ \\
23.35 & 720 & 136.89 & $19.01 \%$ \\
23.35 & 740 & 147.49 & $19.93 \%$ \\
22.50 & 760 & 165.23 & $21.74 \%$ \\
22.25 & 780 & 178.91 & $22.94 \%$ \\
21.75 & 800 & 195.36 & $24.42 \%$ \\
21.75 & 820 & 207.73 & $25.33 \%$ \\
21.25 & 840 & 225.38 & $26.83 \%$ \\
21.25 & 860 & 238.46 & $27.73 \%$ \\
21.25 & 880 & 251.79 & $28.61 \%$ \\
21.25 & 900 & 265.36 & $29.48 \%$ \\
\hline
\end{tabular}




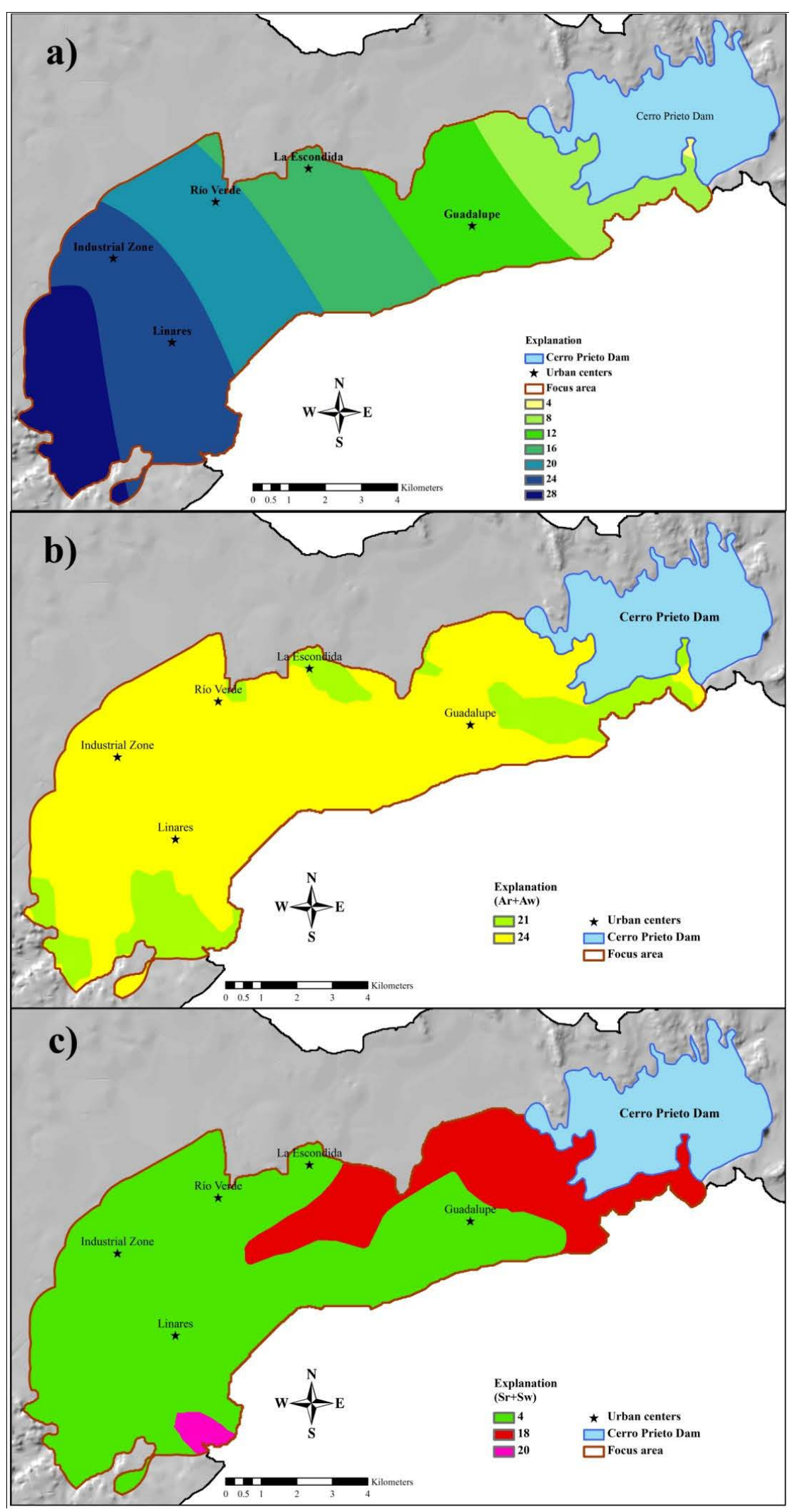

Figure 3. (a) Recharge over the study area and related values; (b) Aquifers distribution and related values; (c) Soil distribution and its ratings values. 
Based on information from the hydrostratigraphic units the aquifer media were classified as follow: a) the sedimentary rocks with low to medium $\mathrm{K}$ takes a value of 8 ; and $\mathrm{b}$ ) the fractured shale (Méndez Formation) receives a value of 7. Table 2 and Figure 3(b) shows the values and the aquifers distribution respectively [43] [54][57]. The soil map was took from a previous thesis about the potential erosion in the basin developed by Reyes-Reyna (2000), where the soil type allows defining ratings with values of 10 for lithosols, 9 for regosols and 2 for vertisols. The distribution and the ratings values are express in Figure 3(c) and Table 2.

On the other hand the Digital Elevation Model (DEM) was created from two analogical topographical maps (Scale: 1:250,000 [52]; Scale: 1:50,000 [58]), these maps have been complemented with several coordinate points that were collected during the field campaigns using GPS measurements (Garmin EtrexHCx). In total around 95,000 points conforms the database and the riverbed elevation was taking into account to generate the model using the interpolator procedure "Topo to Raster" which allows to generate topographic relieves with a good accurate; Table 2 shows the rating values and Figure 4(a) represents the geographical distribution of topographical slope with ratings from 10 ( $0 \%$ of slope) to 1 (>18\% of slope). The nature of the vadose zone was

Table 2. DRASTIC rating and weighting values for the hydrogeological parameter settings according to Aller et al. (1987).

\begin{tabular}{|c|c|c|c|c|}
\hline DRASTIC Parameters & Range & Rating & Weight & Total weight (rating $\times$ weight) \\
\hline \multirow{7}{*}{ Recharge (mm) } & 126.62 to 136.89 & 1 & 4 & 4 \\
\hline & 136.89 to 147.49 & 2 & 4 & 8 \\
\hline & 147.49 to 165.23 & 3 & 4 & 12 \\
\hline & 165.23 to 178.91 & 4 & 4 & 16 \\
\hline & 178.91 to 195.36 & 5 & 4 & 20 \\
\hline & 198.35 to 207.73 & 6 & 4 & 24 \\
\hline & 207.73 to 225.38 & 7 & 4 & 28 \\
\hline \multirow{3}{*}{ Aquifer Media } & Conglomerate & 8 & 3 & 24 \\
\hline & Fractured Shale & 7 & 3 & 21 \\
\hline & Litosols & 10 & 2 & 20 \\
\hline \multirow[t]{6}{*}{ Soil Media } & Regosols & 9 & 2 & 18 \\
\hline & Vertisols & 2 & 2 & 4 \\
\hline & 0 to 2 & 10 & 1 & 10 \\
\hline & 2 to 4 & 9 & 1 & 9 \\
\hline & 4 to 6 & 8 & 1 & 8 \\
\hline & 6 to 8 & 7 & 1 & 7 \\
\hline \multirow{7}{*}{ Slope \% } & 8 to 10 & 6 & 1 & 6 \\
\hline & 10 to 12 & 5 & 1 & 5 \\
\hline & 12 to 14 & 4 & 1 & 4 \\
\hline & 14 to 16 & 3 & 1 & 3 \\
\hline & 16 to 18 & 2 & 1 & 2 \\
\hline & $>18$ & 1 & 1 & 1 \\
\hline & Fractured Shale & 6 & 5 & 30 \\
\hline \multirow[t]{3}{*}{ Impact of the vadose zone } & Uniform graves & 8 & 5 & 40 \\
\hline & Alluvium & 9 & 5 & 45 \\
\hline & $10^{-1}$ to $10^{-3}$ & 10 & 3 & 30 \\
\hline \multirow[t]{2}{*}{ Conductivity (m/s) } & $10^{-3}$ to $10^{-5}$ & 8 & 3 & 24 \\
\hline & $10^{-6}$ to $10^{-8}$ & 4 & 3 & 12 \\
\hline
\end{tabular}




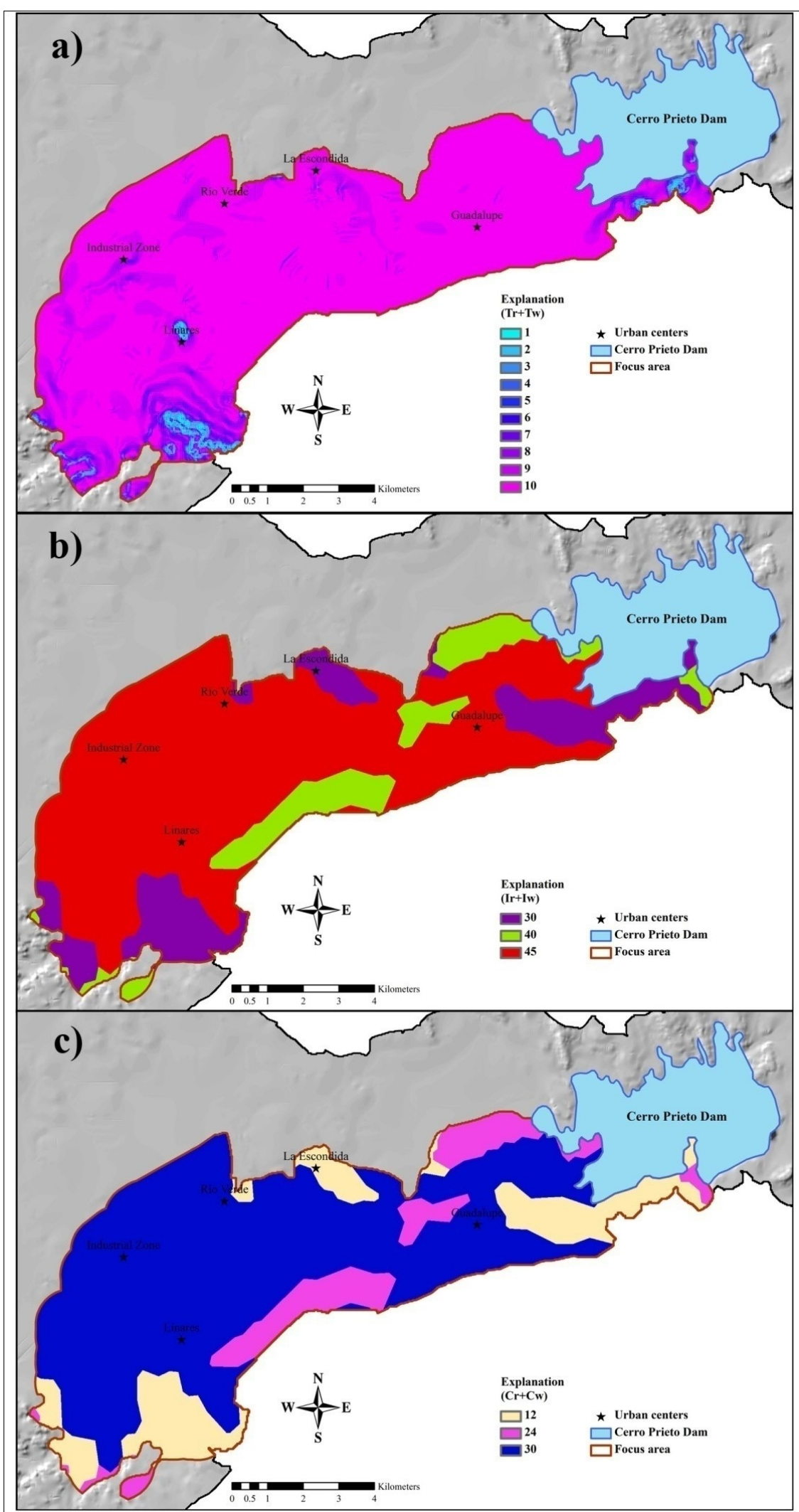

Figure 4. (a) Geographical distribution of topographical slope; (b) Vadose zone distribution; (c) Hydraulic conductivity of the aquifers. 
determined by analyzing wells drilled profiles, previous geological information and verifications during the field campaigns; the assigned ratings range between 6 (shale) and 9 (silt, sand and gravel), these values are show in Table 2 and Figure 4(b). Finally, the hydraulic conductivity is based on general values proposed by Fetter (2000) in accordance with the lithological aquifer characteristics, Figure 4(c) shows the distribution over the area and Table 2 shows its values. The final DVI is calculated through the addition of the reclassified raster datasets of each parameter. Each cell $(10 \times 10 \mathrm{~m})$ of each thematic map is calculate with the values of overlapping cells of the other six parameters considered by the method, in this way the final vulnerability index of each cell of the vulnerability map.

\subsection{Groundwater Levels Trend}

Between the years 2001 and 2007 the dynamic groundwater levels were manually measured every month in 22 wells (data of 2002 does not exist) inside the study area. These measurements allows to evaluate the general trend of groundwater levels, the stacked line charts was used to show the trend of the contribution of each value over time or ordered categories, but since not easy to see that the lines are stacked, consider using a type of graph lines which represents the water table since sea levels as a reference point. Figure 5 contents the lines of each measured well from January 2001 to December of 2007. A general trend was found, the groundwater levels since November 2006 a strong tendency of groundwater depletion. This general trend allows defining the selected dataset for the present analysis. With this reduced database, two water table maps were created for November 2001 and April 2007 by the interpolation of these measurements using the Inverse Distance Weight Method (IDW). Water tables were rating and reclassified according to Table 3 and are showed in Figure 6(a) and Figure 6(c).

\subsection{The Impact of Groundwater Levels on DRASTIC Assessment}

Two aquifers vulnerability maps were develop to know the importance of groundwater levels in the assessment procedure using the DRASTIC method. The time difference between the assessments is $\sim 5$ years and 6 months, the effects of water table on the system was analyze using two piezometric measurements, this means a key change in the border conditions of the model. Following the procedure of the method two models were developed to obtain the vulnerability maps for 2001 (Figure 6(b)) and 2007 (Figure 6(d)) at the end a comparison and analysis was done.

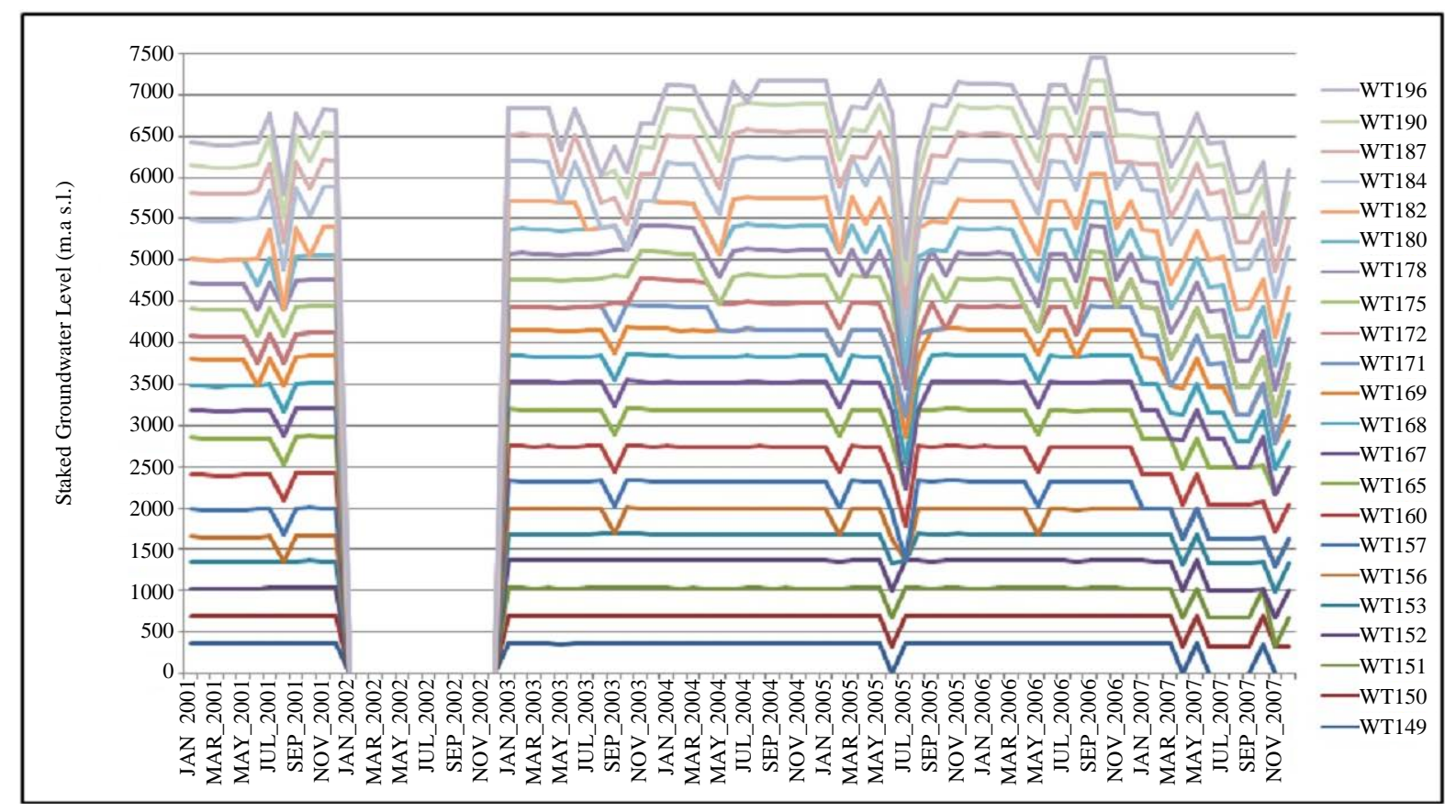

Figure 5. Groundwater levels trend (2001-2007). 
Table 3. Depth to water table and its rating values for each case.

\begin{tabular}{|c|c|c|c|c|c|}
\hline \multicolumn{3}{|c|}{2001} & \multicolumn{3}{|c|}{2007} \\
\hline \multicolumn{2}{|c|}{ Depth } & \multirow{2}{*}{$\begin{array}{c}\text { DRASTIC } \\
\text { Rating value }\end{array}$} & \multicolumn{2}{|c|}{ Depth } & DRASTIC \\
\hline \multicolumn{2}{|c|}{ (Meters) } & & \multicolumn{2}{|c|}{ (Meters) } & Rating value \\
\hline 0.00 & 9.39 & 10 & 0.00 & 9.39 & 10 \\
\hline 9.39 & 12.14 & 9 & 9.39 & 12.14 & 9 \\
\hline 12.14 & 14.33 & 8 & 12.14 & 14.33 & 8 \\
\hline 14.33 & 16.25 & 7 & 14.33 & 16.25 & 7 \\
\hline \multirow[t]{6}{*}{16.25} & 18.31 & 6 & 16.25 & 18.31 & 6 \\
\hline & & & 18.31 & 20.64 & 5 \\
\hline & & & 20.64 & 23.66 & 4 \\
\hline & & & 23.66 & 28.06 & 3 \\
\hline & & & 28.06 & 33.41 & 2 \\
\hline & & & 33.41 & 39.99 & 1 \\
\hline
\end{tabular}

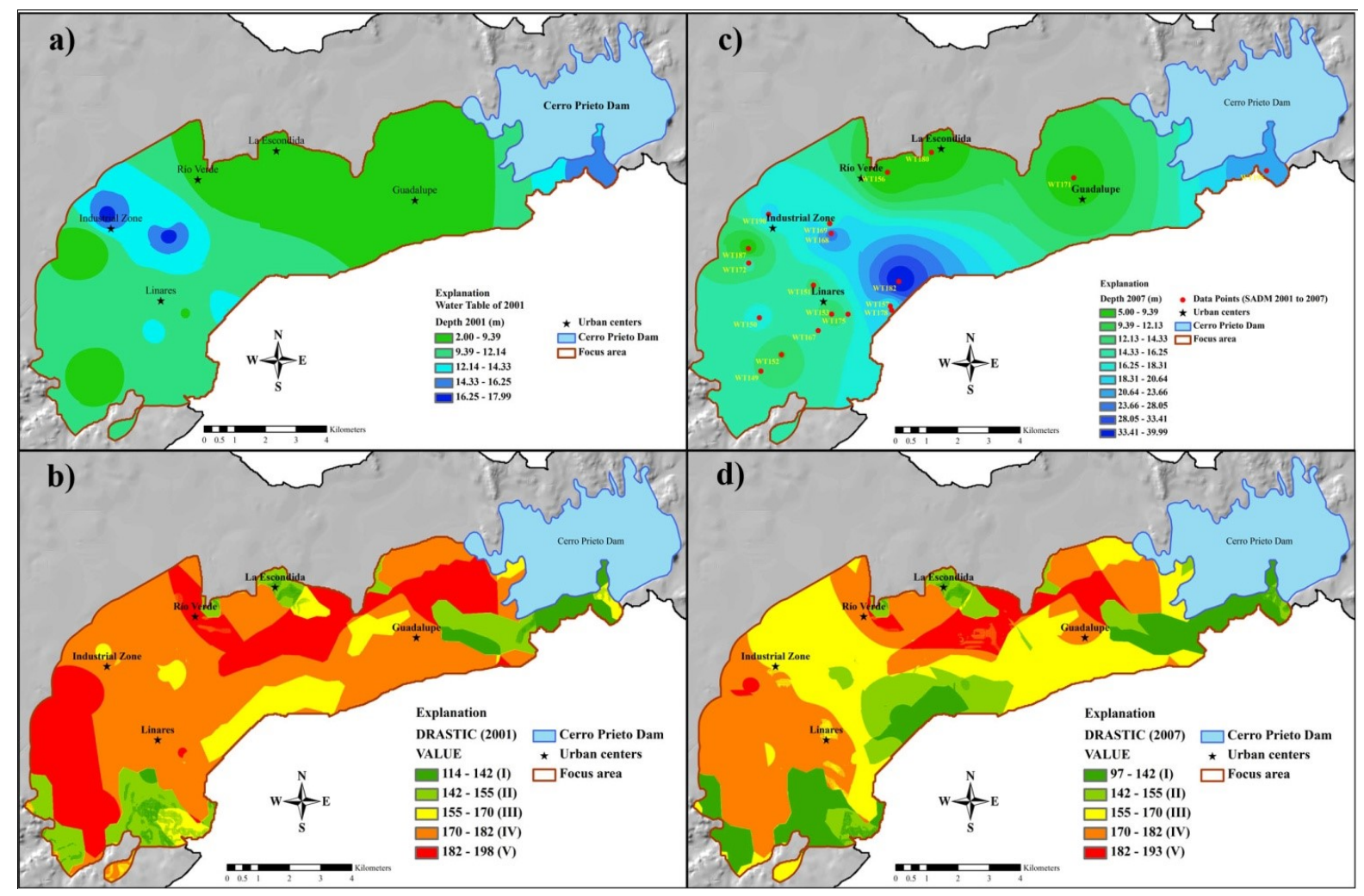

Figure 6. (a) Water table distribution (2001); (b) DRASTIC index value (2001); (c) Water table distribution (2007); (d) DRASTIC index value (2007).

\subsection{The Significance of Land-Use to Find the Risk to Pollution Index}

On the other hand, the land-use map (Figure 7(a)) was obtained by digitizing the official map of land-use of INEGI for 1982, the city map of Linares of the Local Government for 2007 and an actualization of the urban border with GPS measurements developed in the same year. The resulting map (shape file) was converted to a 
"raster dataset" and then was reclassified using the rating values suggested by Panagopoulos et al., (2006), the ratings of land-use were weighted by a factor of 5 this represents the overriding importance of land-use on aquifer vulnerability; Table 4 represents the numerical values of each category and Figure 7(b) show the spatial distribution of these categories. This parameter is use as a fingerprint of human activities in Linares city and its surroundings.

\subsection{Land-Use and Its Relation to the Nitrate Levels in Groundwater}

The reclassified land-use map was combined with the DVI map of 2007 to obtain the Index of Pollution Risk, as groundwater levels and land-use are more sensible short-term dynamic variables in the model can be combined. This relationship is due to groundwater depletion depends on the extracted volume of groundwater which is the direct result of the volume of water required to meet different human needs. Therefore, equal importance of groundwater levels and land-use was assumed. The reclassified values from the depths of the water table and land-use (according to the table given by Panagopoulos et al., (2006) were combined into the "Raster calculator" where the arithmetic average between land-use and groundwater levels of each cell was calculated. The result is a raster set with values ranging between 5 and 50 (Figure 7(b)).

In order to relate the human impact activities over the aquifer vulnerability the land-use was used (Figure 7(b)) as a parameter to correct the DVI map for 2007. The introduction of this dynamic variable into the mathematical procedure DRASTIC method is possible if it affects only a dynamic parameter considered by the method. The unique dynamic parameter in DRASTIC is Depth to water table, this parameter can affect the DRASTIC final Index significantly as it know now. The rating land-use values can be combined with depth to water table in order to relate the human activity with groundwater extraction that is a result of agricultural, industrial and urban development. This modification allows generating the Index of Pollution Risk with the following modification to the equation of DRASTIC method:

$$
I P R=\left(\frac{D r D w+L U r L U w}{2}\right)+R r R w+A r A w+S r S w+T r T w+I r I w+C r C w
$$

where:

$I P R=$ Index of Pollution Risk

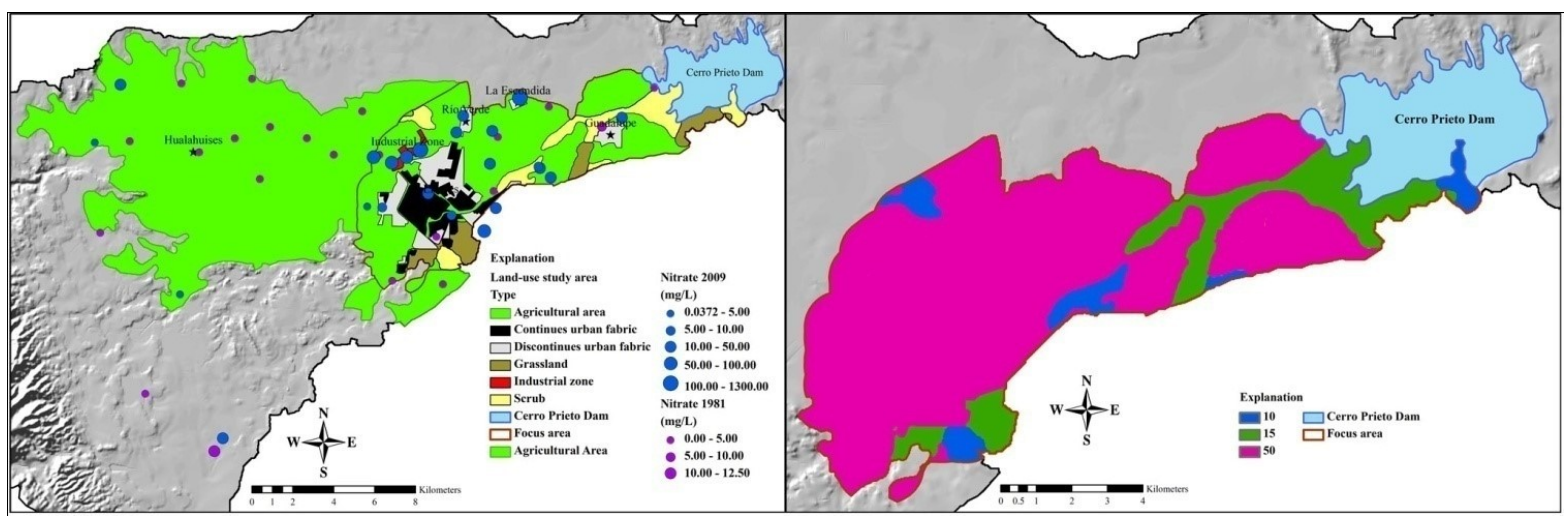

Figure 7. Land use distribution (left) and parametric values of land use distribution (right).

Table 4. Typical land-use ratings given by panagopoulos et al., (2006).

\begin{tabular}{ccccc}
\hline DRASTIC Additional parameter & Range & Rating & Weight & Total Weight (rating $\times$ weight) \\
\hline Land-use & Shrub & 2 & 5 & 10 \\
& Natural grassland & 3 & 5 & 5 \\
50 & Farm & 10 & 5 & 50 \\
\hline
\end{tabular}




\section{$L U=$ Land-use}

In Equation (3) all the variables not detailed in the explanation are the original ones of the DRASTIC method. The resulting map presents the risky groups (Figure 8(a)), which have the same groups limits of the DRASTIC vulnerability used for DVI-2001, DVI-2007 and IPR-2007, the same group classification allows to makes comparisons between these three scenarios.

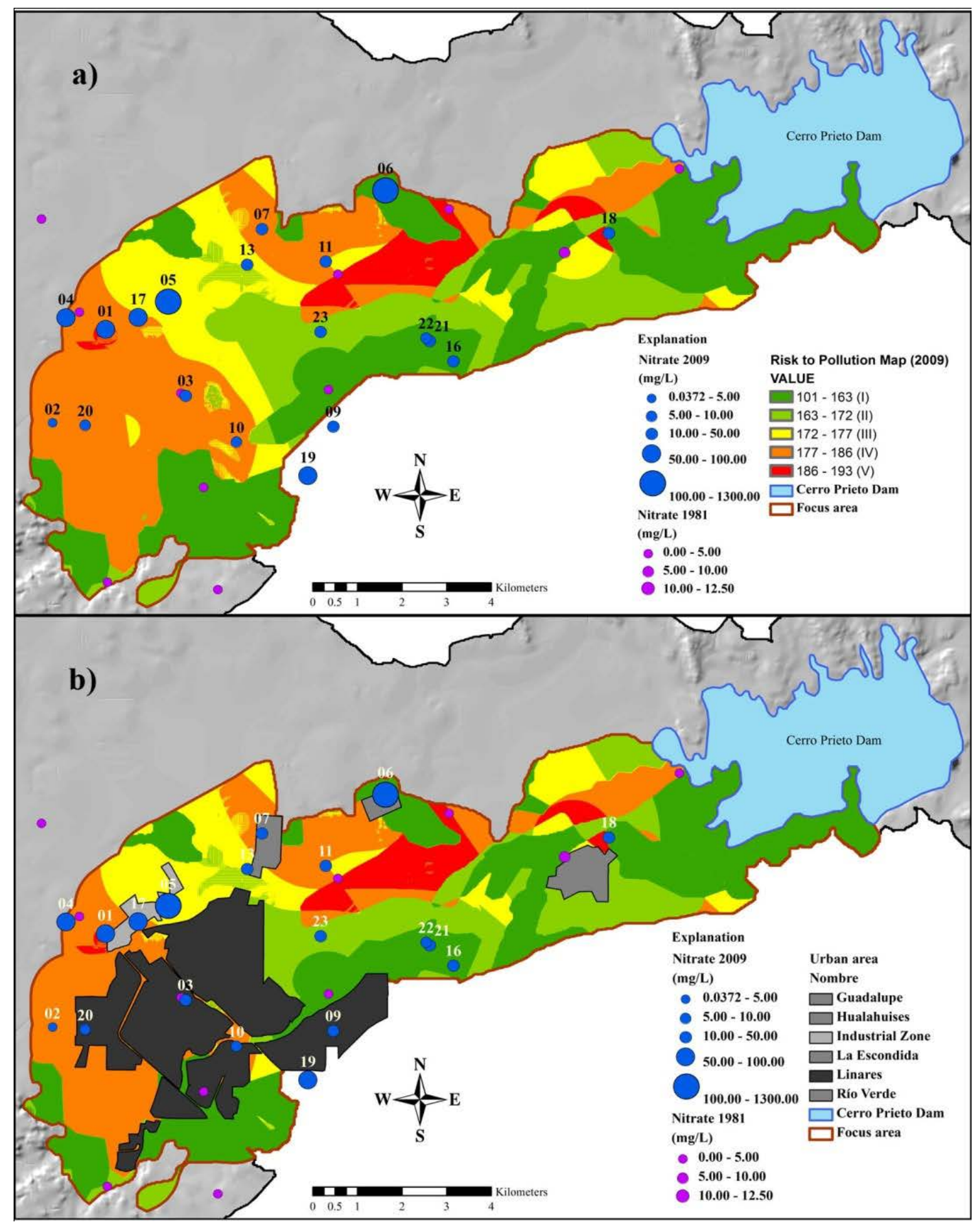

Figure 8. (a) Risk to pollution map (2009) and nitrate distribution (1981-2009); (b) Urban settlement correlation with risk to pollution distribution and nitrate presence. 


\subsection{Validation of Index of Pollution Risk Map}

The validation of the proposed map (IPR) can be done through the nitrate distribution analysis. The use of nitrate as a pollution indicator is helpful to know the evolution and changes of groundwater quality. In the particular study case, the nitrate differences between a previous situation (1981) and the present situation (2009) was analyzed. During 1981 a total of 25 wells were used to determine the nitrate content, which are located mostly in the agricultural belt surrounding the city of Linares, where the main propose of the extracted water was irrigation [57], that period represents the previous scenario to the agricultural explosion. On the other hand, 23 wells were sampled in 2009 to determine the actual nitrate content, the sampling points was defined according to the main land-use distribution in the actual situation. The final nitrate values after the chemical analysis of groundwater samples for both cases are used to know the impact of human activities on groundwater quality (Figure 8(b)).

\section{Results}

\subsection{DRASTIC Assessment for 2001}

The maximum range of the DVI has to be between 23 and 230 points, according to this specification, in this study the obtained vulnerability range for 2001 is between 114 and 198. Then the vulnerability of the basin can be classified into five groups, i.e. V-The very high (182 - 198); IV—The high (170 - 182), III-The medium (155 - 170); II-The low (142 - 155) and I-The very low (114 - 142) (Table 5 and Figure 6(b)). The quantile classification was applied to define these five groups; this statistical method distributes a set of data into groups with equal number of values. The extreme values from 23 to 113 and 183 to 230 represents the lowest and highest possible vulnerability in the numerical range of DRASTIC method which should not be considered due to the particular site characteristics of the area. These groups of values (23 - 113 and 183 - 230) fall outside automatically during the rating step of each parameter considered by the method.

\subsection{DRASTIC Assessment for 2007}

In order to assess the aquifer vulnerability in 2007 the water table depth of 2007 has been introduce in the model because groundwater depths change over time. Figure 6(c) shows the water table levels and Table 3 include the reclassified values of groundwater depths (dimensionless data). The hypothesis that constant values behavior for: aquifer media, soil type, topography, vadose zone and hydraulic conductivity were assumed because these parameters can change its characteristics only during a long term. The vulnerability map for 2007 was classified into the same group limits of the assessment for 2001: i.e. V—very high (182 - 193); IV—high (170 - 182), III— medium (155 - 170); II—low (142 - 155) and I-very low (97 - 142) (Table 5 and Figure 6(d)), this procedure allows the comparison between both scenarios. As a result, the differences between the models show the important role of groundwater levels, which reflect the groundwater overexploitation produced by agricultural and industrial activities between 2001 and 2007. The most relevant is the highest vulnerability value in 2001 of 198 (6 points higher than the maximum of 2007), interestingly the groundwater depletion results in a decrease of vulnerability, it is demonstrated that the depth to the groundwater table is a most sensitive parameter in DRASTIC due to its weighting factor (equal to 5) and its variability over time, which is directly related to human activities.

Table 5. DRASTIC vulnerability index for 2001 and 2007, coverage surface of each category.

\begin{tabular}{|c|c|c|c|c|c|c|c|c|}
\hline \multirow{3}{*}{$\begin{array}{c}\text { DVI } \\
\text { Category } \\
\text { I }\end{array}$} & \multicolumn{4}{|c|}{2001} & \multicolumn{4}{|c|}{2007} \\
\hline & \multicolumn{2}{|c|}{ Values } & \multirow{2}{*}{$\begin{array}{c}\text { Area }\left(\mathrm{km}^{2}\right) \\
4.13\end{array}$} & \multirow{2}{*}{$\begin{array}{c}\% \\
4.79\end{array}$} & \multicolumn{2}{|c|}{ Values } & \multirow{2}{*}{$\begin{array}{c}\text { Area }\left(\mathrm{km}^{2}\right) \\
13.56\end{array}$} & \multirow{2}{*}{$\begin{array}{c}\% \\
15.72\end{array}$} \\
\hline & 114 & 142 & & & 97 & 142 & & \\
\hline II & 142 & 155 & 9.39 & 10.88 & 142 & 155 & 10.03 & 11.62 \\
\hline III & 155 & 170 & 8.76 & 10.16 & 155 & 170 & 27.43 & 31.79 \\
\hline IV & 170 & 182 & 41.70 & 48.32 & 170 & 182 & 29.31 & 33.97 \\
\hline \multirow[t]{2}{*}{ V } & 182 & 198 & 22.32 & 25.86 & 182 & 193 & 5.96 & 6.90 \\
\hline & & & 86.29 & $100.00 \%$ & & & 86.29 & $100.00 \%$ \\
\hline
\end{tabular}


The pollution potential over the outcrops of the fractured aquifer in the piedmonts and headwaters belongs to the group V in both cases (2001 and 2007), denoting a strong importance of geological patterns. The interaction between the hydrogeological settings and water table levels are the most important parameters into the vulnerability assessment with DRASTIC method. When the water table is close to the surface into a fractured aquifer the increase in pollution potential is important, in the contrary scenario the pollution potential decreases significantly.

The vulnerability map of 2007 looks quite different compared with vulnerability map of 2001; In the oldest scenario (2001), the V-very high and IV-high categories of DVI are placed in the west area, the central part is less vulnerable (where Linares city is placed). For 2007 categories V and IV reduces they area (Figure 6(b) and Figure 6(d)). The same behavior can be appreciated on the east area near to Cerro Prieto Dam, where a belt of category V is present in 2001; for 2007 this area reduces its coverage. In the central part of the focus area the vulnerability values changes significantly i.e. in 2001 the predominant category of DVI was IV and a tin belt of category III is placed in the central-south portion; in 2007 this area changes the category mostly to category III and the DVI categories II and I appears. The general behavior of decreasing DVI values happed due to deeper level of the water table. This scenario allows confirming the significant exploitation of groundwater volumes under and surround Linares city. In the initial situation (2001) groundwater was extracted only from the porous shallow aquifer, nowadays the groundwater extraction is both aquifers i.e. the porous aquifer (alluvial-conglomerate Formation) and from the deeper and fractured aquifer (Méndez Formation). This change of water levels somehow seems to hide the potential vulnerability of the aquifers.

\subsection{Index of Pollution Risk Maps}

The IPR Map (Figure 8(a)) has greater values of risk to pollution in the northwest area from Linares coinciding with areas of high aquifer vulnerability in 2001 (Figure 6(b)). In Table 6 the values of IPR can be observed where obtained range goes from 101 to 197, the final groups in the IPR map are: V-very high risk (182 - 197); IV—high risk (170 - 182); III—moderate risk (155 - 170); II—low risk (142 - 155) and I—very low risk (101 142). The same classification limits was take in order to be possible the comparison in terms of distribution and surface coverage of each category (Table 5 and Table 6).

This map looks quite different to the DVI map for the same period (2007) and it has great similarities with the $D V I$ map for the initial situation (2001). Table 6 shows the distribution of values for IPR and the groups order comparison between DVI-2001, DVI-2007 and IPR-2007. After the coverage areas calculation was done, an interesting situation was found in the dominant categories order between DVI of 2001 and IPR of 2007, where the categories order are very similar for both cases (Table 6), i.e. the proposal modification allows reaching a more realistic scenario with the conditions of the aquifer.

\subsection{Nitrate Distribution in 1981 and 2009}

In relation to nitrate values for 1981, low nitrate levels were identified in 21 out of the 25 samples which have a nitrates concentration below $2.5 \mathrm{mg} / \mathrm{l}$. The highest concentration was $12.4 \mathrm{mg} / \mathrm{l}$, well below the WHO guideline level for nitrate in drinking water $(50 \mathrm{mg} / \mathrm{l})$; this fact indicates that at that time no groundwater pollution was

Table 6. Index of pollution risk and groups order comparison between DVI-2001, DVI-2007 and IPR-2007.

\begin{tabular}{|c|c|c|c|c|c|c|c|}
\hline \multirow{3}{*}{$\begin{array}{c}\text { DVI } \\
\text { Category } \\
\text { I }\end{array}$} & \multicolumn{4}{|c|}{ Index of Pollution Risk (IPR) } & \multicolumn{3}{|c|}{ Groups order } \\
\hline & \multicolumn{2}{|c|}{ Values } & \multirow{2}{*}{$\begin{array}{c}\text { Area }\left(\mathrm{km}^{2}\right) \\
6.76\end{array}$} & \multirow{2}{*}{\begin{tabular}{|c|}
$\%$ \\
7.83
\end{tabular}} & \multirow{2}{*}{$\begin{array}{c}\text { DVI-2001 } \\
5\end{array}$} & \multirow{2}{*}{$\frac{\text { DVI-2007 }}{3}$} & \multirow{2}{*}{$\begin{array}{c}I P R-2007 \\
5\end{array}$} \\
\hline & 101 & 142 & & & & & \\
\hline II & 142 & 155 & 10.47 & 12.13 & 3 & 4 & 4 \\
\hline III & 155 & 170 & 10.95 & 12.69 & 4 & 2 & 3 \\
\hline IV & 170 & 182 & 30.60 & 35.46 & 1 & 1 & 1 \\
\hline \multirow[t]{2}{*}{$\mathrm{V}$} & 182 & 197 & 27.51 & 31.88 & 2 & 5 & 2 \\
\hline & & & & $100.00 \%$ & & & \\
\hline
\end{tabular}


present due to agricultural activities. The nitrate distribution was almost homogeneous in the central and northern portions of the agricultural area, for these areas the vulnerability categories were IV-high and V-very high, this situation was due to the shallow groundwater depth and deeper alluvial deposits. At this time the impact of human activity was insignificant; this behavior is corroborated by nitrate values below the WHO concentrations. In the present situation (2009) only 6 wells have nitrate concentrations below $10 \mathrm{mg} / \mathrm{l}$, the geospatial distribution of these samples show predominance close to the riversides through the city (samples 02, 20, 10 and 22) from west to east. In the range between 10 and $50 \mathrm{mg} / \mathrm{l}$ were determinate 11 samples its distribution show 9 samples distributed in Linares and its surroundings areas following a direction from west to east (samples 03, 13, 07, 09, 23, 11, 21, 16 and 18). Finally, the 6 samples with contents over $50 \mathrm{mg} / \mathrm{l}$ are concentrated over a small area to the northwest of Linares city around the industrial area and downstream after the agricultural main area of the basin (04, 01, 17, 05, 19 and 06). The highest nitrate value is present in sample 06 located downstream of the city, industrial area and main agricultural zones, due to the geometry of the basin the groundwater paths are grouped at this basin section before reach the body's dam. In contrary, the situation on 1981 has predominance of low than $10 \mathrm{mg} / \mathrm{l}$ nitrate values; only one sample located on headwaters exceeds $10 \mathrm{mg} / \mathrm{l}$ with a value of 12.4 $\mathrm{mg} / \mathrm{l}$.

\section{Discussion}

The impact of groundwater levels on aquifer vulnerability is clearly demonstrated between the initial scenario (2001) and the recent scenario (2007), where the dominant DRASTIC categories changes significantly in this short period, i.e. in 2001 the order of dominant categories was IV—high vulnerability; V-very high vulnerability; II—low vulnerability; III—-moderate vulnerability and I—very low vulnerability, that means $74.18 \%$ (64.02 $\mathrm{km}^{2}$ ) of the all area has high values of vulnerability (categories IV and V), the moderate vulnerability covers only $10.16 \%\left(8.76 \mathrm{~km}^{2}\right)$ and the lower values (categories II and I) covers only $15.67 \%\left(13.52 \mathrm{~km}^{2}\right)$ of the study area $\left(86.29 \mathrm{~km}^{2}\right)$. Almost three times of the surface covered by the sum of the categories I, II and II belong to values with greater potential pollution. In the assessment realized with the data of 2007 a very different scenario was obtained, where the dominant categories order was: IV—high vulnerability; III-moderate vulnerability; I-very low vulnerability; II - low vulnerability and V-very high vulnerability, where the areas coverage is: $33.97 \%, 31.79 \%, 15.72 \%, 11.62 \%$ and $6.90 \%$ respectively. The total higher value (categories IV and V) has $40.87 \%\left(35.27 \mathrm{~km}^{2}\right)$, the moderate vulnerability covers $31.79 \%\left(27.43 \mathrm{~km}^{2}\right)$ and the lower categories (I and II) covers $27.34 \%\left(23.59 \mathrm{~km}^{2}\right)$ of the all study area. Surprisingly, in both cases category IV is dominant, its coverage area change $19.01 \mathrm{~km}^{2}$ being smaller in 2007. But the most interesting change is the one who suffers the category $\mathrm{V}$ from $22.32 \mathrm{~km}^{2}$ to $5.96 \mathrm{~km}^{2}$ losing an area of coverage of $16.36 \mathrm{~km}^{2}$, which is more than 3.7 times less high-risk area of vulnerability. The category III in 2001 was located on the fourth of dominance, but in 2007 reached the second place due to the increase in its coverage area which is equal to $18.67 \mathrm{~km}^{2}$ thereby tripling its coverage area of 2001. Unexpected, the category I rise to third in order of dominance category, increasing its surface in $9.43 \mathrm{~km}^{2}$, which represents 3.28 times of growth. The more stable is category II, which does not vary significantly its coverage, i.e., in 2001 had an area equal to $9.39 \mathrm{~km}^{2}$ and in 2007 covers an area equal to 10.03 $\mathrm{km}^{2}$. All these values come from Table 5 analysis.

The spatial distribution obtained with DRASTIC category in 2001 is very different from the spatial distribution obtained for 2007. In 2001 the category V, covered the western sector of the study area predominantly, his second area of dominance was located between north of Linares city and the western edge of Cerro Prieto dam. The category IV cover's from the central west to the western edge of Cerro-Prieto Dam also covers the most central of the study area from north to south, interrupted only by a belt of category I, II and V near the western limit of Cerro Prieto. Category III is present in an randomly distribution, main sectors, are in the central-south part of the study area, two other sectors are between the west part of "Guadalupe" and the east part of La Escondida and small. The categories II and I area divided into three main sectors, the area of greatest topographic slope to the southwest of Linares, the second area covered by these categories is located at the east of the study area, finally a small areas in the central area close to the Industrial zone. The scenario in 2007 presents a more heterogeneous distribution, categories I and II is divided into five sections: two are placed in the area of high slopes to the southwestern part, the third section is located in the east part close to Cerro Prieto dam, surprisingly the fourth sector is in the central zone (east of Linares city) where anthropogenic activities are concentrated, finally, two small areas adjacent to northern and western edges the study area. Category III extends from the 
northern border in the central and splits into two branches, the least of them to the south and the most important in a southeasterly direction towards the Cerro Prieto dam. Category IV is concentrated in two main sectors, the first located west of the study area covering a larger area and the second extends from the western edge of Cerro Prieto dam northwest to reach the northern edge near the town called "Río Verde". Finally the category V is located mainly in one area which is located northeast of the study area encompassed by the category IV and the second extends from the central zone (between Linares city and Cerro-Prieto dam) with northeast direction near of the location knows as "Guadalupe".

According to the analysis in the preceding paragraphs, apparently the current situation (2007) is much better in terms of groundwater vulnerability, but the economic and urban development of Linares city, the location of new industries in the Industrial Zone and the increase in citrus production needs further extension of the acreage which indicates that there is a greater probability of emission of pollutants, therefore higher risk aquifers contamination is predictable, which completely contradicts the situation determined by the application of the DRASTIC method in 2007.

In order to correct the vulnerability map generated for 2007, land-use was introduced as a new parameter in the DRASTIC method, which is directly related to human activity and groundwater exploitation. This modification according Equation 3, allowed to obtain the IPR, the result is a map which can be classified in groups while maintaining the limits of each class interval calculated for determining the vulnerability map in 2001. The order of the key risk categories is as follows: IV-high risk; V-very high risk; III-moderate risk; II-low risk and I-very low risk. The distribution of coverage areas are: $30.60 \mathrm{~km}^{2}, 27.51 \mathrm{~km}^{2}, 10.95 \mathrm{~km}^{2}, 10.47 \mathrm{~km}^{2}$ and $6.76 \mathrm{~km}^{2}$ respectively. The higher risky values (categories V and IV) sum a total significance of $67.34 \%$, the moderate values has only $12.69 \%$ (category III) and the lower values (categories I and II) has the $17.23 \%$ of the all area. This situation can be correlated with the DVI map for 2001 because a similar order of the dominant classes. The main differences are the coverage area of each category, i.e. $11.1 \mathrm{~km}^{2}$ more in DVI-2001 than IPR in category IV; $5.19 \mathrm{~km}^{2}$ more in $I P R$ than $D V I-2001$ in category V and $2.63 \mathrm{~km}^{2}$ more in IPR than DVI-2001 in category I. The most important similitude are for categories I, II and III, categories IV and V has more sensibility to change its category by the land-use impact in the model.

On the other hand, the intensive agriculture increases the potential pollution, which is not accounted for in the basic approach of DRASTIC method. This situation is ascertained by the nitrate distribution and concentrations for 2009 which are high over the area, the highest values are placed close the industrial zone of Linares (Figure $7(a)$ ). The values of nitrate are increasing progressively from the Industrial Zone to the Cerro Prieto Dam (from west to east), this situation is directly correlated with the groundwater pathways which explains the highest nitrate value in the downstream area of Linares city where the risk to pollution category is I-very low (Figure 7(a)). For this particular case, vadose zone seems to plays the retaining role of pollutants in its body as a result to less volume of recharge and infiltration that is why the contaminants cannot reach easily the water table. Hence, nitrate can work as a indicator of pollution and its main application could be the validation of aquifer vulnerability maps taking into account the dynamic variables like time and nitrate distribution due to land-use.

Interestingly, the higher nitrate values corresponds to the Industrial Zone and the agricultural areas close to Linares city, the coverage of category $\mathrm{V}$ in terms of risk is similar and comparable with the coverage area of category V of the vulnerability map for 2001. As expected, the highest nitrate value is downstream the city (La Escondida, sample 06), but surprisingly this point falls within the category which represents the least risk to pollution (category I). A possible explanation to this unusual situation are the pathways of groundwater flux, the possible pollutant sources are located upstream of this point, i.e. Agricultural area, Industrial Zone and Urban centers (Linares, Hualahuises, Río Verde and La Escondida) which pour waste water to the rivers and the use of pesticides is a custom over the agricultural area. This point could represent a critic situation due to its proximity to the Cerro Prieto water reservoir which threatens the drinking water source of the metropolitan area of Monterrey. Additionally, most of the samples in 2009 have nitrate concentrations higher values than the WHO water human consumption recommendations, which means a high risk to the health of the inhabitants of urban centers within the study area. Groundwater sources provide more than $50 \%$ of the total volume of potable water in the region. The evolution of nitrate contents over the area shows clearly the impact of agriculture and industry in groundwater quality. The analysis of nitrate distribution in groundwater was possible through the comparison between two situations: the first (1981) represents the initial stage of agricultural booming in the region, as expected the nitrate levels are low where the maximum value reaches only $12.4 \mathrm{mg} / \mathrm{l}$ and the second situation (2009) represents the current state of nitrates in groundwater, this scenario shows that nitrate levels in most ex- 
ceed the WHO standards. The difference in values between 1981 and 2009 is very significant showing a modification process of the groundwater quality in the aquifers of the region.

The high level of nitrate proved the deterioration of groundwater quality, which is affected mainly in the north and northeast of the study area (samples 04, 01, 12, 05 and 06). The high nitrates values are located on areas of land-use destinated to industry and urban development, but mainly suggested a transport route of nitrate from agricultural activities (chic cover most of the northwest outside the study area) around Hualahuises city to the east until reach west edge of the Cerro-Prieto dam. This scenario reflects the impact of human activities around Linares city. Moreover, overlaying the nitrate values of 2009 (Figure 8(b)) over the IPR map of 2007 and the urban centers a direct and good correlation is present between increased nitrate concentrations, high risky areas and human settlements (categories IV and V).

\section{Conclusions}

DRASTIC method is a useful tool to assess intrinsic aquifer vulnerability from a regional point of view due to its versatility of its procedure and the integration of more hydrogeological parameters in comparison with other methods like GOD, AVI and SINTACS.

DRASTIC assessment is valid for situations where a specific time, for this reason cannot be extrapolated to assess the aquifer vulnerability in a long term. In this study, it is proved that six of the seven parameters considered in the DRASTIC method change its properties in a very long term.

The depth from surface to groundwater plays an important role by being the most dynamic variable over time. This study shows that the depth of water table is the key factor in the evaluation of groundwater vulnerability. Even in a short period ( $\sim 5$ years), results from DRASTIC method can rely solely on groundwater level variations, if the physical conditions of the aquifer are constant.

For this particular case, the behavior of the recharge is hypothetically considered as constant because the time between analyses is less than 10 years and a normal climatologic condition predominates for this period.

Land-use proved to be an important parameter necessary to correct the vulnerability maps using the DRASTIC method. This variable can be introduced without any problem in the calculation procedure using GIS platform.

The IPR results developing in this study could be a key variable for implementing control policies, to help decision makers and implement programs for sustainable groundwater management in urban environment of the most cities in Latin America because it easy, cost effective and environmentally valuable.

\section{Acknowledgements}

Research leading to this paper has been partially supported by the Universidad Autónoma de Nuevo Leon, México, PAICyT project CT 1584-07 (2008). Thanks to the regional program of PhD study supported by the Deutscher Akademischer Austausch Dienst, Deutschland (D.A.A.D.) which was developed in Facultad de Ciencias de la Tierra/UANL, México and for the sandwich scholarship to realize a scientific period in the Institüt fur Angewandte Geowissenschaften/Technische Universität Darmstadt. The authors would also like to thank the associate editor and the anonymous reviewers for their valuable and constructive comments.

\section{References}

[1] Margat, J. (1968) Vulnèrabilitè des nappes d'eau souterrune à la pollution (Groundwater Vulnerability to Contamination). Bases de al cartographie (Doc.) 68 SGC 198HYD, BRGM, Orleans.

[2] Aller, L., Bennett, T., Lehr, J.H., Petty, R.H. and Hackett, G. (1987) DRASTIC: A Standardized System for Evaluating Ground Water Pollution Potential Using Hydrogeologic Settings. Robert S. Kerr Environmental Research Laboratory, Ada.

[3] Foster, S.S.D. (1987) Fundamental Concepts in Aquifer Vulnerability, Pollution Risk and Protection Strategy. In: Van Duijvenbooden, W. and Van Waegenigh, H.G., Eds., Vulnerability of Soil and Ground Water Pollutants, TNO Committee on Hydrological Research Information, The Hague, 69-86.

[4] Van Stempvroort, D., Ewert, L. and Wasseernaar, L. (1992) AVI: A Method for Groundwater Protection Mapping in the Praire Province of Canada. National Hydrology Research Institute, Saskatoon.

[5] Civita, M. (1994) Le Carte della vulnerabilit a degli acquiferi all’inquinamiento: Teoria e Pratica (Contamination Vulnerability Mapping of the Aquifer: Theory and Practice). Quaderni di Tecniche di Protezione Ambientale, Pitagora.

[6] Jamrah, A., Futaisi, A.A., Rajmohan, N. and Al-Yaroubi, S. (2007) Assessment of Groundwater Vulnerability in the 
Coastal Region of Oman Using DRASTIC Index Method in GIS Environment. Environmental Monitoring and Assessment, 147, 125-138. http://dx.doi.org/10.1007/s10661-007-0104-6

[7] Panagopoulos, G.P., Antonakos, A. and Lambrakis, N.J. (2006) Optimization of the DRASTIC Method for Groundwater Vulnerability Assessment via the Use of Simple Statistical Methods and GIS. Hydrogeology Journal, 14, 894-911. http://dx.doi.org/10.1007/s10040-005-0008-X

[8] Wang, Y., Merkel, B.J., Li, Y., Ye, H., Fu, S. and Ihm, D. (2007) Vulnerability of Groundwater in Quaternary Aquifers to Organic Contaminants: A Case Study in Wuhan City, China. Environmental Geology, 53, 479-484. http://dx.doi.org/10.1007/s00254-007-0669-y

[9] Ahmed, A.A. (2009) Using Generic and Pesticide DRASTIC GIS-Based Models for Vulnerability Assessment of the Quaternary Aquifer. Hydrogeology Journal, 17, 1203-1217. http://dx.doi.org/10.1007/s10040-009-0433-3

[10] Al-Zabet, T. (2002) Evaluation of Aquifer Vulnerability to Contamination Potential Using DRASTIC Method. Environmental Geology, 43, 203-208. http://dx.doi.org/10.1007/s00254-002-0645-5

[11] Cameron, E. and Peloso, G.F. (2001) An Application of Fuzzy Logic to the Assessment of Aquifers’ Pollution Potential. Environmental Geology, 40, 1035-1315.

[12] Kim, Y. and Hamm, S. (1999) Assessment of the Potential for Groundwater Contamination Using the DRASTIC/EGIS Technique, Cheongju Area, South Korea. Hydrogeology Journal, 7, 227-235. http://dx.doi.org/10.1007/s100400050195

[13] Melloul, A.J. and Collin, M. (1998) A Proposed Index for Aquifer Water Quality Assessment: The Case of Israel's Sharon Region. Journal of Environmental Management, 54, 131-142. http://dx.doi.org/10.1006/jema.1998.0219

[14] Merchant, J. (1994) GIS-Based Groundwater Pollution Hazard Assessment: A Critical Review of the DRASTIC Model. Photogrammetric Engineering and Remote Sensing, 60, 1117-1127.

[15] Rosen, L. (1994) A Study If the DRASTIC Methodology with Emphasis on Swedish Conditions. Ground Water, 32, 278-285. http://dx.doi.org/10.1111/j.1745-6584.1994.tb00642.x

[16] Kalinski, R.J., Kelly, W.E., Bogardi, I., Ehrman, R.L. and Yamammoto, P.O. (1994) Correlation between DRASTIC Vulnerabilities and Incidents of VOC Contamination of Municipal Wells Nebraska. Ground Water, 32, 31-34. http://dx.doi.org/10.1111/j.1745-6584.1994.tb00607.x

[17] McLay, C., Dragden, R., Sparling, G. and Selvarajah, N. (2001) Predicting Groundwater Nitrate Concentrations in a Region for Mixed Agricultural Land Use: A Comparison of Three Approaches. Environmental Pollutant, 115, 191-204. http://dx.doi.org/10.1016/S0269-7491(01)00111-7

[18] Garrett, P., Williams, J.S., Rossoll, C.F. and Tolman, A.L. (1989) Are Ground Water Vulnerability Classification Systems Workable? Proceedings of FOCUS Conference on Eastern Regional Ground Water Issues, Kitchener, 17-19 October, 329-343.

[19] Vbra, J. and Zaporozec, A. (1994) Guidebook on Mapping Groundwater Vulnerability. Verlag Heinz Heise, Hannover.

[20] Lee, S. (2003) Evaluation of Waste Disposal Site Using the DRASTIC System in Southern Korea. Environmental Geology, 44, 654-664. http://dx.doi.org/10.1007/s00254-003-0803-4

[21] Mendoza, J.A. and Barmen, G. (2006) Assessment of Groundwater Vulnerability in the Río Antiguas, Nicaragua. Environmental Geology, 50, 569-580.

[22] Secunda, S., Collin, M. and Melloul, A.J. (1998) Groundwater Vulnerability Assessment Using a Composite Model Combining DRASTIC with Extensive Land Use in Israel’s Sharon Region. Environmental Management, 54, 39-57. http://dx.doi.org/10.1006/jema.1998.0221

[23] Sener, E., Sener, S. and Davraz, A. (2009) Assessment of Aquifer Vulnerability Based on GIS and DRASTIC Methods: A Case Study of the Senirkent-Uluborlu Basin (Isparta, Turkey). Hydrogeology Journal, 17, 2023-2035. http://dx.doi.org/10.1007/s10040-009-0497-0

[24] Laskar, A. (2003) Integrating GIS and Multi-Criteria Decision Making Techniques for Land Resource Planning. Master's Thesis, International Institute for Geo-Information Science and Earth Observation, Enschede.

[25] Eldrandaly, K., Eldin, N., Sui, D., Shouman, M. and Nawara, G. (2005) Integrating GIS and MCDM Using COM Technology. The International Arab Journal of Information Technology, 2, 162-167.

[26] Barrett, M.H. (2004) Characteristics of Urban Groundwater. In: Lerner, D.N., Ed., Urban Groundwater Pollution, A.A. Balkema Publishers, Rotterdam, 29-50.

[27] Foster, S., Lawrence, A. and Morris, B. (1998) Groundwater in Urban Development: Assessing Management Needs and Formulating Policy Strategies. World Bank Technical Paper No 390.

[28] Lerner, D.N. (2004) Urban Groundwater Pollution. Taylor \& Francis, London.

[29] Ward, M.H., de Kok, T.M., Lellallois, P., Brender, J., Gulis, G., Nolan, B.T. and VanDerslice, J. (2005) Workgroup Report: Drinking-Water Nitrate and Health—Recent Findings and Research Needs. Environmental Health Perspectives, 
113, 1607-1614.

[30] Canter, L.W. (1997) Nitrates in Groundwater. Lewis, Boca Raton.

[31] INEGI (2010) Censo de Población y Vivienda 2010. Instituto Nacional de Estadística, Geografía e Informática, Aguascalientes.

[32] Dávila Pórcel, R.A. (2011) Desarrollo sostenible de usos de suelo en ciudades en crecimiento, aplicando Hidrogeología Urbana como parámetro de planificación territorial: Caso de estudio Linares. Doctorado en Ciencias con especialidad en Geociencias, Universidad Autónoma de Nuevo León, Nuevo León.

[33] Beller, H., Eaton, G.F., Ekwurzel, B.E., Esser, B.K., Hu, Q., Hudson, G.B., Leif, R., McNab, W., Moody-Bartel, C., Moore, K. and Moran, J.E. (2005) California GAMA Program: Sources and Transport of Nitrate in Groundwater in the Livermore Valley Basin. Lawrence Livermore National Laboratory (LLNL), Livermore.

[34] Edmunds, W.W. and Gaye, G.B. (1997) Naturally High Nitrate Concentrations in Ground Waters from the Sahel. Journal of Environmental Quality, 26, 1231-1239. http://dx.doi.org/10.2134/jeq1997.00472425002600050006x

[35] Hossain, F., Hill, J. and Bagtzoglou, A.C. (2007) Geostatistically Based Management of Arsenic Contaminated Ground Water in Shallow Wells of Bangladesh. Water Resources Management, 21, 1245-1261. http://dx.doi.org/10.1007/s11269-006-9079-2

[36] Hussain, I., Raschid, L., Hanjra, M., Marikar, F. and van der Hoek, W. (2001) A Framework for Analyzing Socioeconomic, Health and Environmental Impacts of Wastewater Use in Agriculture in Developing Countries. Working Paper 26, International Water Management Institute (IWMI), Colombo.

[37] Kass, A., Gavrieli, I., Yechieli, Y., Vengosh, A. and Starinsky, A. (2005) The Impact of Freshwater and Wastewater Irrigation on the Chemistry of Shallow Groundwater: A Case Study from the Israeli Coastal Aquifer. Journal of Hydrology, 300, 314-331. http://dx.doi.org/10.1016/j.jhydrol.2004.06.013

[38] Tang, C., Chen, J., Shindo, S., Sakura, Y., Zhang, W. and Shen, Y. (2004) Assessment of Groundwater Contamination by Nitrates Associated with Wastewater Irrigation: A Case Study in Shijiazhuang Region, China. Hydrological Processes, 18, 2303-2312. http://dx.doi.org/10.1002/hyp.5531

[39] Vázquez, J.C.G., Grande, J.A., Barragán, F.J., AOcaña, J.A. and Torre, M.L.D.L. (2005) Nitrate Accumulation and Other Components of the Groundwater in Relation to Croppings in an Aquifer in Southwestern Spain. Water Resources Management, 19, 1-22.

[40] Li, F.M., Song, Q.H., Liu, H.S., Li, F.R. and Liu, X.L. (2001) Effects of Pre-Sowing Irrigation and Phosphorus Application on Water Use and Yield of Spring Wheat under Semi-Arid Conditions. Agricultural Water Management, 49, 173-183. http://dx.doi.org/10.1016/S0378-3774(01)00087-7

[41] Zizhen, L. and Hong, L. (1998) Research on the Regulation of Water and Fertilizers and a Crop Growth Model of Spring, Wheat in Farmland of Semi-Arid Regions. Ecological Modelling, 107, 279-287. http://dx.doi.org/10.1016/S0304-3800(98)00004-0

[42] De Cserna, Z. (1956) Tectónica de la Sierra Madre Oriental de México, entre Torreón y Monterrey, México. XX Congreso Geológico Internacional, Mexico City, 87.

[43] De León-Gómez, H. (1993) Die Unterläufigkeit der Talsperre José López Portillo/Cerro Prieto auf einer KalksteinMergelstein —Wechselfolge bei Linares, Nuevo León/Méxiko. Ph.D. Dissertation, RWTH Aachen, Aachen.

[44] Ruíz-Martínez, M.A. (1990) Zur Gliederung Verbreitung und Ökologischen Bewertung der Böden in der Region von Linares, N.L. Mexiko. Diplomarbeit, Georg-August-Universität Göttingen, Göttingen.

[45] Ruíz-Martínez, M.A. and Werner, J. (1997) Research into the Quaternary Sediments and Climatic Variations in NE Mexico. Quaternary International, 43-44, 145-151. http://dx.doi.org/10.1016/S1040-6182(97)00030-X

[46] Mao, Y.Y., Zhang, X.G. and Wang, L.S. (2006) Fuzzy Pattern Recognition Method for Assessing Groundwater Vulnerability to Pollution in the Zhangji Area. Journal of Zhejiang University Science A, 7, 1917-1922. http://dx.doi.org/10.1631/jzus.2006.A1917

[47] CNA (2002) Determinación de la disponibilidad de agua en el acuífero Citrícola sur, estado de Nuevo León. Comisión Nacional del Agua, Mexico City, 1-22.

[48] CNA (2007) Base de datos hidrometeorológicos, estaciones climatologicas e hidrométricas ubicadas al interior de la Cuenca del Río Pablillo. Monterrey.

[49] CNA (2007) Estadísticas del Agua en México. Primera Edición, 2007 edn Comisón Nacional del Agua, Mexico City.

[50] INEGI (1977) Carta Edafológica (Linares G14-C58), Escala 1:50000. Instituto Nacional de Estadística, Geografía e Informática, Aguascalientes.

[51] INEGI (1983) Carta Geológica (Linares G14-11), Escala 1:250000. Instituto Nacional de Estadística, Geografía e Informática, Aguascalientes.

[52] INEGI (2006) Carta Topográfica (Linares G-14-11), Escala 1:250.000. Instituto Nacional de Estadística, Geografía e 
Informática, Aguascalientes.

[53] ESRI (2010) ArcGIS 9.3. Environmental Systems Research Institute (ESRI), Redlands.

[54] De la Garza-González, S.I. (2000) Estudio geológico/hidrogeológico de la región citrícola Linares-Hualahuises, Nuevo León, NE-México. Tesis de Licenciatura, Facultad de Ciencias de la Tierra, Universidad Autónoma de Nuevo León, Nuevo León.

[55] INEGI (1977) Carta Geológica (G14-C67), Escala 1:50000. Instituto Nacional de Estadística, Geografía e Informática, Aguascalientes.

[56] SGM (2009) Carta Geológico-Minera Hoja Linares 84-G14-11_GM Servicio Geológico Mexicano.

[57] INEGI (1983) Carta Hidrológica de Aguas Subterráneas (Linares G14-11), Escala 1:250000. Instituto Nacional de Estadística, Geografía e Informática, Aguascalientes.

[58] INEGI (1999) Carta Topográfica (Linares G-14-C58), Escala 1:50000. Segunda Edición, Instituto Nacional de Estadística, Geografía e Informática, Aguascalientes. 
Scientific Research Publishing (SCIRP) is one of the largest Open Access journal publishers. It is currently publishing more than 200 open access, online, peer-reviewed journals covering a wide range of academic disciplines. SCIRP serves the worldwide academic communities and contributes to the progress and application of science with its publication.

Other selected journals from SCIRP are listed as below. Submit your manuscript to us via either submit@scirp.org or Online Submission Portal.
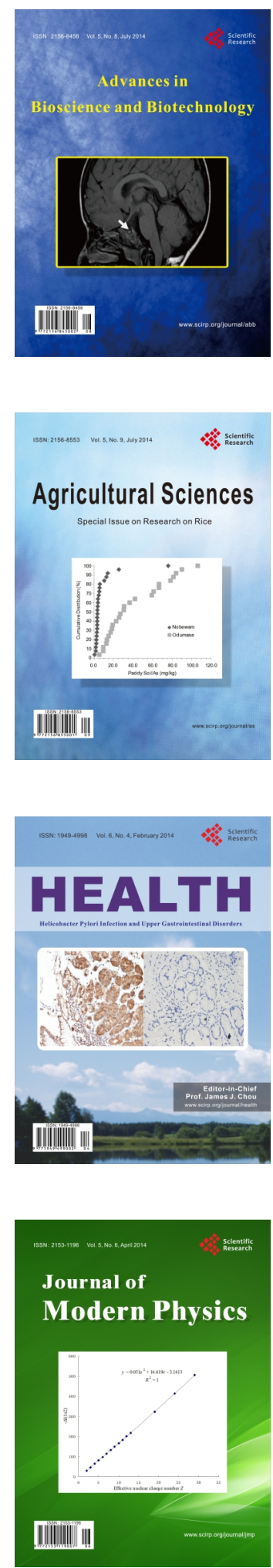
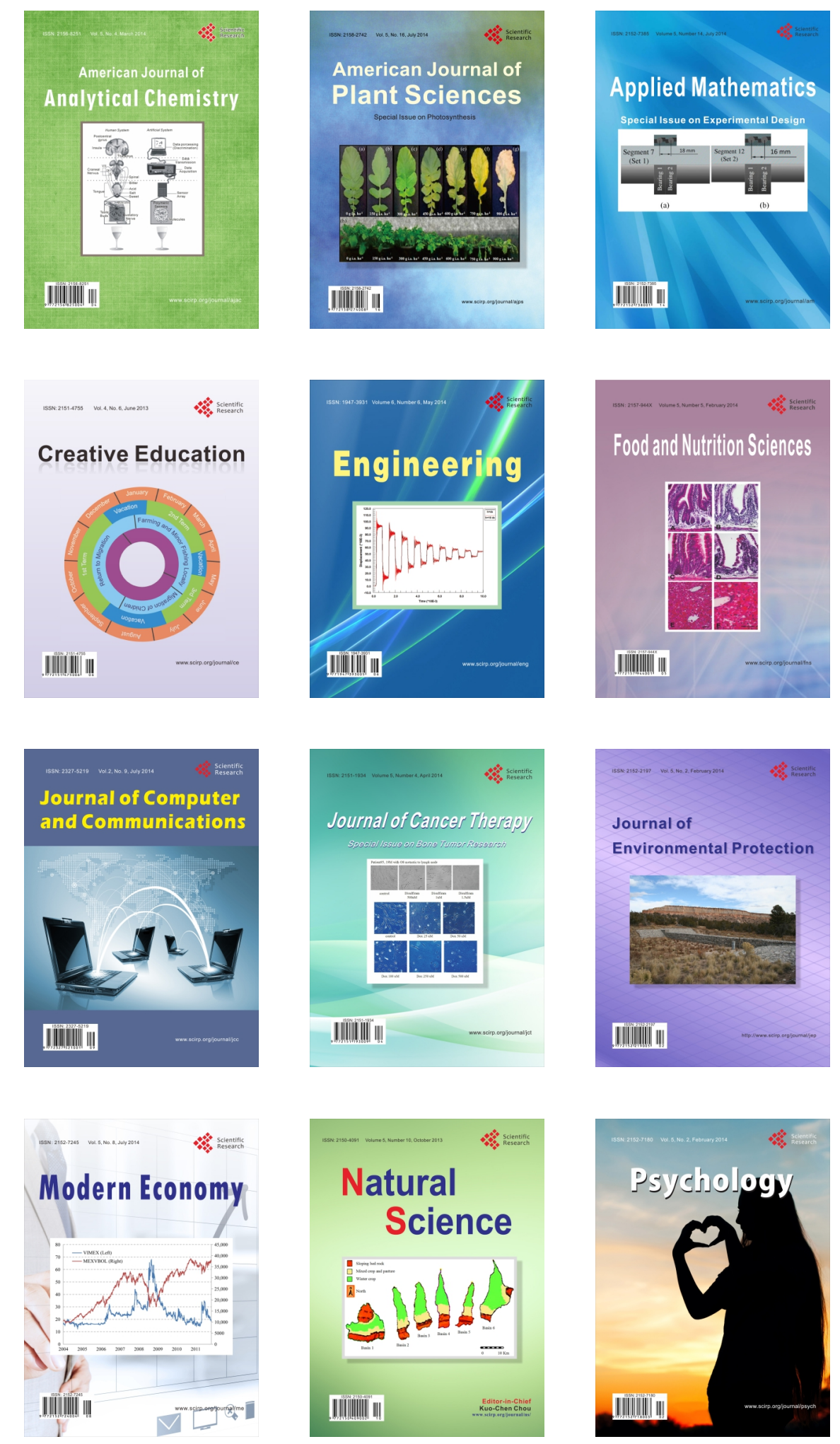